\title{
Inflation targeting works well in Latin America
}

\author{
José García-Solanes and Fernando Torrejón-Flores
}

ABSTRACT

This paper analyses the macroeconomic effects of inflation targeting (it) in five Latin American countries during the period 2000-2007. We perform three types of econometric tests, which coincide in showing that it regimes have contributed to decreasing the level and variability of both the rate of inflation and the short-term interest rate, compared with a group of non-it Latin American countries. Moreover, our empirical analysis clearly reveals that it has led to lower variability in gdp growth, but the net effects on the level of economic growth remain unclear. The main technical innovation of this paper is the estimation of a treatment effects model to solve the endogeneity problem of adopting it, which is inherently present in most of the econometric tests applied so far in this field.

KEYWORDS

JEL CLASSIFICATION

AUTHORS
Inflation, monetary policy, macroeconomics, econometric models, economic growth, economic indicators, Latin America, Brazil, Chile, Colombia, Mexico, Peru

E52, F21, F33

José García-Solanes, Faculty of Economics and Business Studies, University of Murcia, Spain. solanes@um.es

Fernando Torrejón-Flores, Faculty of Law and Business Studies, San Antonio Catholic University of Murcia, Spain. ftorrejon@pdi.ucam.edu 


\section{I}

\section{Introduction}

Many empirical studies prove that the emerging market economies (EMEs) with inflation targeting (IT) regimes have succeeded in lowering their inflation rates. Calderón and Schmidt-Hebbel (2003a, 2003b) showed that the IT countries (ITers) in Latin America and the Caribbean have been able to systematically reduce both inflation rates and inflation-target misses after adopting this monetary regime. Lin and Ye (2009) obtained a similar result using a variety of propensity score matching methods in 13 developing countries. Corbo, Landerrechte and Schmidt-Hebbel (2002) and Gonçalves and Salles (2008) discovered that, compared with non-targeters (NITers), developing countries adopting the IT framework experienced greater drops not only in inflation but also in output growth volatility. Valdés (2007) found similar results in Chile. Batini and Laxton (2007) and the International Monetary Fund (IMF) (2005 and 2006) report even larger macroeconomic benefits in terms of lower and less volatile inflation, as well as lower volatility of interest rates, exchange rates, international reserves and output growth, when compared with countries that have not adopted IT. Finally, Brito and Bystedt (2010) also find that IT reduces inflation, inflation volatility and output growth volatility in EMEs, although the effects are less strong and significant than noted in previous literature.

The final results of IT hinge for the most part upon the capability of IT to strengthen credibility and to decrease inflation expectations in developing countries. ${ }^{1}$ Proponents

We thank Arielle Beyaert, Enrique Alberola and Josep Lluís Carrión-i-Silvestre for their very helpful comments on the econometric methodology applied in this paper, and we thank seminar participants at the ninth Annual Conference of the International Network for Economic Research (INFER) on monetary and economic integration in Europe held at Loughborough University in October 2007, the fifth Conference on Economic Integration held at Universitat Jaume I in November 2007, and the eleventh Conference on International Economics held at the University of Barcelona in June 2009. Financial support from the Fundación Séneca, Project 15183/PHCS/10, is gratefully recognised. All errors are our own.

${ }^{1}$ A similar debate exists in the literature concerning the suitability of IT regimes in transition economies. On the one hand, Jonás and Mishkin (2005) and Hrncir and Smidkova (2003), for instance, believe that, although inflation-targeting central banks face particular difficulties in these countries (such as predicting inflation under increased uncertainty and suffering more frequent shocks), such regimes could still deliver important benefits in terms of increased control over expectations and short-term flexibility of monetary policy. On the other hand, Kvasnicka (2000) considers that IT regimes are not advisable for transition economies because such economies are strongly affected of IT offer an optimistic view on the grounds that the pote ntial of credibility gains is high since developing countries generally start implementing this regime with very weak institutions. Svensson (1997), Mishkin (1999), King (2005), IMF (2006) and Blejer and others (2001) advised the adoption of IT regimes in EMEs during IMF structural adjustment programmes. Other distrustful authors claim that some kind of "original sin" in institutions and structural drawbacks in policy implementation preclude the central banks of these economies from reducing inflation expectations consistently (Calvo and Mishkin, 2003; Sims, 2005; Blanchard, 2005).

The empirical analysis of the macroeconomic impact of IT requires solving the endogeneity bias created by the adoption of an IT regime. To our knowledge, Brito and Bystedt (2010) is the only work to address this problem explicitly and seriously in the context of emerging market economies. For the period 1980-2006, these authors analysed the impact of IT on inflation and output growth in 13 IT developing countries, using as benchmarks several control groups from a sample of 33 non-IT emerging economies. They applied the two-step S-GMM panel estimator, which controls for the timevarying bias problem and for the endogeneity of the IT regime. Their findings indicate that the EMEs with IT strategies have been successful with disinflation, but at the cost of hindering output growth.

In this paper, we tackle and solve the endogeneity problem by estimating (after the application of two conventional regression tests) a treatment effects model, following the procedure suggested by Heckman (1979), Maddala (1983) and Greene (2003). This method is particularly suited for evaluating the impact of qualitative variables, such as the adoption of IT, on other variables that are easily quantified. It consists of estimating a probit relationship aimed at assessing the extent to which some variables picked out from theory and from the empirical literature affect the probability of adopting an IT regime, and outcome equations that relate some macroeconomic variables with their main determinants, among which the adoption of IT is a key variable.

by uncertainties and instability in the monetary policy transmission mechanism. In the framework of eight developed countries, Yigit (2010) showed IT effectiveness in reducing inertia in inflation expectations. 
Our analysis focuses on five Latin American countries that adopted an IT regime by the end of 2007, taking another set of 10 non-IT Latin American economies as a benchmark for the years 1980-2007. For several reasons, Latin America does indeed provide an interesting case study for assessing the effects of IT on emerging market economies. First, the five Latin American targeters have been the forerunners of IT in the worldwide group of emerging market economies. Second, choosing a panel composed of only Latin American countries allows for minimizing economic and institutional differences between the members of the panel; this helps to better isolate the effects of adopting IT. In fact, we work with a group of economies that are more homogeneous than those usually considered in the literature.

Our panel treatment methodology is not distorted by time-varying bias because all countries of the group started applying full-fledged IT around 2000, which is also the year in which our analysis of the treatment effects begins. Small differences in dates of IT adoption cannot bias the results significantly. Furthermore, there is no evidence that the Latin American countries in our sample have been affected by different time trends since 2000 . There are also reasons to believe that our methodology correctly addresses the self-selection problem because the variables that led each country to adopt the IT framework are determined endogenously in our model. We can assert, then, that the econometric treatment effects methodology contributes to improving the inference of the causal effect of IT on the selected macroeconomic variables, compared with other methodologies that do not correctly deal with the time-varying bias and the self-selection problem.

The paper is structured in four sections. After this introduction, in section II we perform a descriptive analysis using all three of the candidate variables (rate of inflation, short-term interest rate and economic growth) for the two groups of countries, in order to intuitively grasp the impact of IT on them. In section III we apply three different econometric tests to rigorously investigate the impact of IT on the level and variability of those three variables. Finally, section IV summarizes the main empirical findings.

The results that we derive from the empirical analysis may be summarized as follows. The regression and treatment effects tests coincide to show that IT has decisively contributed to reducing both average levels and variability of domestic inflation and short-term interest rates and to decreasing variability of GDP growth compared with alternative monetary regimes during the period under study. Although the final effect on the level of GDP growth cannot be clearly discerned - which is not surprising given the relatively short length of the observed period- our results point out that the IT regime has improved macroeconomic results compared with other policy regimes that are not equipped with an explicit inflation expectations anchor.

\section{II}

\section{Descriptive Analysis}

In this section we apply descriptive statistics to get a first impression of the likely macroeconomic effects of the adoption of IT in five Latin American countries: Brazil, Chile, Colombia, Mexico and Peru. The general methodology is as follows: (i) for each ITer, we compare the results relating to some relevant macroeconomic variables during the pre-IT era with those of the post-IT period of the same country, and (ii) we compare the results (for the same set of variables) that each group of countries (ITers and NITers) obtained during the post-IT period of the first group. The group of NITers selected as a benchmark comprises 10 countries: Argentina, the Bolivarian Republic of Venezuela, Costa Rica, Dominican Republic, Ecuador, El Salvador, Panama, Paraguay, the Plurinational State of Bolivia and Uruguay. Both groups of countries are in Latin America because this enables us to compare areas that share not only an analogous geographical context but also similar degrees of economic and institutional development.

As a prior step, it is useful to describe the exchangerate regimes in force in the countries of the sample over the entire period of analysis. The 15 selected countries offer not only a variety of different exchange-rate regimes but also a number of very different monetary arrangements. Table 1 shows the exchange-rate regimes declared by these countries to the IMF in three different years: 1985,2002 and 2007. As can be seen, the general tendency is a switch from intermediate regimes towards corner solutions: while in 198512 of the 15 countries had exchange-rate regimes that represented intermediate 
Latin America: exchange-rate regimes, 1985, 2002 and 2007

\begin{tabular}{|c|c|c|c|}
\hline \multirow{2}{*}{ ITers countries } & 1985 & 2002 & 2007 \\
\hline & \multicolumn{3}{|c|}{ Exchange-rate regimes } \\
\hline Brazil & Intermediate & Flotation & Flotation $(\mathrm{IF})^{*}$ \\
\hline Chile & Intermediate & Flotation & Flotation $(\mathrm{IF})^{*}$ \\
\hline Colombia & Intermediate & Flotation & Flotation (MF)* \\
\hline Mexico & Intermediate & Flotation & Flotation $(\mathrm{IF})^{*}$ \\
\hline$\underline{\text { Peru }}$ & Intermediate & Flotation & Flotation $(\mathrm{MF})^{*}$ \\
\hline NITer countries & \multicolumn{3}{|c|}{ Exchange-rate regimes } \\
\hline Argentina & Intermediate & Flotation & Flotation (MF) \\
\hline Bolivia (Plurinational State of) & Flotation & Intermediate & Intermediate $(\mathrm{CP})$ \\
\hline Costa Rica & Intermediate & Intermediate & Intermediate $(\mathrm{CP})$ \\
\hline Dominican Republic & Intermediate & Intermediate & Flotation (MF) \\
\hline Ecuador & Intermediate & Rigid peg & Rigid peg (NS) \\
\hline El Salvador & Intermediate & Rigid peg & Rigid peg (NS) \\
\hline Panama & Rigid peg & Rigid peg & Rigid peg (NS) \\
\hline Paraguay & Intermediate & Flotation & Flotation (MF) \\
\hline Uruguay & Flotation & Flotation & Flotation (MF) \\
\hline Venezuela (Bolivarian Republic of) & Intermediate & Flotation & Rigid peg (CF) \\
\hline
\end{tabular}

Source: A. Berg, E. Borensztein and P. Mauro, "An evaluation of monetary regime options for Latin America”, IMF Working Paper, $\mathrm{N}^{\circ} 02 / 211$, Washington, D.C., International Monetary Fund, 2002; and Berg, Borensztein and Mauro (2002, p.25) and International Monetary Fund (IMF), ("De Facto Classification of Exchange Rate Regimes and Monetary Policy Frameworks", April 2008). [online] http://www.imf.org/ external/np/mfd/er/2008/eng/0408.htm.

Note: $\mathrm{CP}$, crawling peg; IF, independently floating; MF, managed float with no pre-announced exchange-rate path; NS, no separate legal tender; $\mathrm{CF}$, conventional fixed peg.

arrangements, by 2007 the share had fallen to 2 out of 15. According to the empirical study by Calderón and Schmidt-Hebbel (2003b), the structural break took place in 1998, immediately after the Asian crisis.

Among the nine countries with floating currency regimes in 2007, three operate independent and free exchange-rate flexibility and the other six exhibit managed floats with no pre-announced exchange-rate path. The three central banks with independent floating regimes belong to the IT group, and they do not use systematic interventions to dampen fluctuations of their exchange rate.

\section{Inflation targeting in Latin America}

To date, five Latin American countries have adopted inflation targeting strategies with more or less intensity. Mishkin and Savastano (2002) present a detailed analysis of the characteristics of these regimes up to 2001. Table 2 updates, for the five countries, the main features of the IT regimes adopted. The starting dates within parentheses indicate when the central bank began to publish inflation reports.
Chile is the first country (January 1991) that gave independence to its central bank and announced price stability as one of its primary objectives. As a result, the domestic inflation rate decreased gradually. However, it was not until 1999 that the central bank explicitly announced a multi-year target for inflation. In May 2000 the central bank began to issue inflation reports in which it published its baseline inflation forecasts. Healthy public finances and a sound financial system are two key features of the Chilean economy that have supported a full-fledged inflation targeting regime in this country.

In 1999 Brazil started a monetary policy regime with all the key ingredients of an IT regime. The central bank immediately published a comprehensive inflation report. Since then the independence of the central bank of Brazil has been enhanced and increased in order to ensure the success of the IT scheme. Moreover, fiscal deficits must be brought back to levels that remove any possibility of fiscal dominance.

In 1991 the central bank of Colombia started to announce explicit numerical targets for the one-year rate 
TABLE 2

Latin America (five countries): inflation-targeting regimes of individual countries

\begin{tabular}{|c|c|}
\hline Country & Starting date and main features \\
\hline Brazil & $\begin{array}{l}\text { Starting date: June } 1999 \text { (September 1999). } \\
\text { Inflation targets: } 8 \% \pm 2 \%(1999), 6 \% \pm 2 \%(2000), 4 \% \pm 2 \%(2006-2007) \text {. } \\
\text { Inflation report and announcement of multi-year inflation targets. } \\
\text { Weak fiscal position and relatively sound financial system. }\end{array}$ \\
\hline Chile & $\begin{array}{l}\text { Starting date: January } 1991 \text { (May 2000). } \\
\text { Inflation targets: 15\%-20\% (1991), 3.5\% (2000), 2\%-4\% (2001-2007). } \\
\text { Inflation report and announcement of multi-year targets. } \\
\text { Strong fiscal position and relatively sound financial system. }\end{array}$ \\
\hline Colombia & $\begin{array}{l}\text { Starting date: January } 1991 \text { (January 1999). } \\
\text { Inflation targets: } 22 \%(1991), 10 \%(2000), 4.5 \% \pm 0.5 \%(2006), 4 \% \pm 0.5 \%(2007) \text {. } \\
\text { Inflation report and announcement of multi-year targets. } \\
\text { Strong fiscal position and relatively sound financial system. }\end{array}$ \\
\hline Mexico & $\begin{array}{l}\text { Starting date: January } 1996 \text { (April 2000). } \\
\text { Inflation targets: } 20.5 \%(1996),<10 \%(2000), 3 \% \pm 1 \%(2003-2007) \text {. } \\
\text { Inflation report and announcement of multi-year targets. } \\
\text { Strong fiscal position and relatively sound financial system at today. }\end{array}$ \\
\hline Peru & $\begin{array}{l}\text { Starting date: January } 1994 \text { (June } 2002) \text {. } \\
\text { Inflation targets: } 15 \%-20 \%(1994), 3.5 \%-4 \%(2000), 2.5 \% \pm 1 \%(2002-2006), 2 \% \pm 1 \% \text { (2007). } \\
\text { Inflation report and announcement of multi-year targets. } \\
\text { Weak fiscal position, but relatively sound financial system. }\end{array}$ \\
\hline
\end{tabular}

Source: The authors, on the basis of economic reports from the respective central banks.

Note: The dates in parentheses correspond to when the central banks published their first inflation reports.

of inflation. This anti-inflationary strategy failed until 1999 because the central bank continued to give priority to other objectives, especially output stabilization and external competitiveness, whenever these goals were threatened by the inflation target. Furthermore, the budget deficit was not sufficiently controlled until that year. The strategy changed positively in January 1999 when the central bank of Colombia began to publish inflation reports. Moreover, in September 1999 the exchange rate began to float freely. The announcement of multi-year inflation targets since October 2000 has also contributed to the success of the new regime in the past few years.

The central bank of Mexico waited until it acquired sufficient anti-inflationary credibility to put in place a full-fledged IT regime. This occurred in January 1999, when the annual rate of inflation $(12.3 \%)$ was below the 13\% target. In April 2000 the Mexican central bank started to publish its monthly report on inflation.

The announcement of IT in 1994 initiated a period of anti-inflationary success in Peru. The inflation rate fell from levels over 20\% in 1994 to 3\% in 2001. However, Peru's monetary authorities did not gain sufficient credibility during that period because their monetary framework lacked many of the crucial features of an IT regime. Some of these features were the announcement of multi-year inflation targets, publication of inflation reports and mechanisms for making the central bank accountable. By June 2002 these drawbacks were almost completely corrected, and monetary policy started to fulfil the key requirements of a true IT regime.

\section{Macroeconomic results}

In order to get a first insight as to the extent to which an IT regime may have contributed to improving macroeconomic results in the five incumbent Latin American countries, we investigate the results in terms of inflation, bank deposit interest rates and GDP growth. We apply descriptive calculus for both time series and cross-section variables of the two groups of countries.

\section{(a) Descriptive analysis of time series variables}

We assembled a database of monthly data for the relatively long period from January 1981 to December 2007 and computed annualized rates for three relevant variables: inflation, short-term interest rate (bank deposits maturing in one year) and GDP growth. For reasons of data availability, the rates of GDP growth were calculated 
using quarterly observations. The sample is split in two periods in each country, taking into account the starting date of the IT regime. The starting IT date is the moment at which the central bank first published an inflation report. The five ITers started a complete IT regime between January 1999 and June 2002 (see table 3). ${ }^{2}$

The details concerning the length of each subsample are presented in table 3. Sample 1, corresponding to the period preceding IT, excludes the years of hyperinflation in each country. Sample 2 encompasses the period after the adoption of Iт. We consider hyperinflation to be rates of inflation over the 95th percentile in the inflation distribution of the entire sample of Latin American countries.

2 Other authors argue that it took several attempts for full-fledged IT regimes to be introduced. The suggested starting dates are not coincident between authors but are relatively close. Thus, according to Mishkin and Schmidt-Hebbel (2007), the stationary target period started at some moment between January 2001 and January 2003, whereas Batini and Laxton (2007) consider that the date was between the second quarter of 1999 and the first quarter of 2002.
Table 4 shows the average and standard deviation of the monthly rates of inflation computed over twelve months (annual basis) for each subsample and country. As far as level values are concerned, it is clearly apparent that the inflation rate decreased sharply between the first and the second subperiods in each country. Brazil reaped the best results, even without taking into account the huge inflation numbers of its hyperinflation years. On average, in the second period the inflation rate fell to $9 \%$ of the value recorded during the first sample period.

As regards inflation rate variability, the third and fourth columns of table 4 illustrate reductions of a similar order as the average in each country. The fall in variability is especially pronounced in the countries with highest initial inflation levels. To sum up, the improvement in inflation is quite remarkable in all countries and has taken place in both levels and variability.

Table 5 provides information that is similar to that set out in the preceding table, but referring to the annualized nominal interest rate on bank deposits. As can be seen, both the average levels and the standard deviations also decrease substantially in each country. For

TABLE 3

Latin America (five countries): subsamples for each country

\begin{tabular}{lllll}
\hline Country & Sample 1: before IT & Hyperinflation period & IT start & Sample 2: after IT \\
\hline Brazil & Jan. 1981-Aug. 1999 & Feb. 1987-Mar. 1995 & Sept. 1999 & Sept. 1999-Dec. 2007 \\
Chile & Jan. 1981-Apr. 2000 & & May 2000 & May 2000-Dec. 2007 \\
Colombia & Jan. 1981-Dec. 1998 & & Jan. 1999 & Jan. 1999-Dec. 2007 \\
Mexico & Jan. 1981-Mar. 2000 & Apr. 2000 & Apr. 2000-Dec. 2007 \\
Peru & Jan. 1981-May 2002 & July 1988-July 1991 & June 2002 & June 2002-Dec. 2007 \\
\hline
\end{tabular}

Source: The authors, on the basis of economic reports from the respective central banks.

Note: Sample 1 comprises the years before the adoption of Iт. Sample 2 comprises the years after the adoption of IT. Sample 1 excludes the years of hyperinflation. Hyperinflation includes the rates of monthly inflation within the 5\% group of observations with the highest rates of inflation.

TABLE 4

Latin America (five countries): inflation by country

(Annualized monthly observations, percentages)

\begin{tabular}{|c|c|c|c|c|}
\hline \multirow{2}{*}{ Country } & \multicolumn{2}{|c|}{ Average level of inflation on annual basis } & \multicolumn{2}{|c|}{ Standard deviation } \\
\hline & Before IT & After IT & Before IT & After IT \\
\hline Brazil & 97.00 & 7.32 & 81.40 & 3.35 \\
\hline Chile & 15.43 & 3.07 & 8.42 & 1.39 \\
\hline Colombia & 23.32 & 6.93 & 4.34 & 2.26 \\
\hline Mexico & 45.73 & 5.05 & 39.89 & 1.67 \\
\hline Peru & 36.96 & 2.11 & 63.18 & 1.13 \\
\hline Average & 47.85 & 4.29 & 38.08 & 1.53 \\
\hline
\end{tabular}

Source: Authors' calculations on the basis of International Monetary Fund, International Financial Statistics. 
the countries that we include in the empirical analysis, IT clearly contributes to easing the task of monetary policy and to reducing tensions in domestic money and credit markets. Consequently, it is not surprising that IT creates a favourable environment for investment decisions, which in turn should contribute to increasing economic growth in the medium and long term.

Table 6 reports the same information for annualized economic growth, computed with quarterly observations of real GDP. It seems that the adoption of an IT regime comes with a clear reduction in the dispersion of growth outcomes, but its effects on the level of growth are ambiguous: the positive effects are observed only in Brazil and Peru.

\section{(b) Descriptive analysis of cross-section variables}

In order to gain a more comprehensive understanding of the results derived from the adoption of the IT regime, it is useful to compare the macroeconomic performance of two groups of Latin American economies: countries with IT, and countries without IT. In the first group we include the five countries considered in the preceding section; the second group is composed of ten countries: Argentina, the Bolivarian Republic of Venezuela, Costa Rica, Dominican Republic, Ecuador, El Salvador, Panama, Paraguay, the Plurinational State of Bolivia and Uruguay. We compute cross-sectional monthly values for the inflation and interest rates and quarterly rates of change for GDP growth for the period January 2000 to December 2007 for the two groups of countries.

Figure 1 presents the results for the three variables for the two groups of countries. As can be seen, the results support the conclusions of the preceding analysis based on time series variables: compared with countries that did not adopt IT regimes during the sample period, those that engineered IT obtained (i) a lower and less volatile rate of inflation; (ii) lower variability in GDP growth; and (iii) much lower levels and variability in short-term interest rates. The net effects on average GDP growth are unclear.

TABLE 5

Latin America (five countries): annualized interest rate on bank deposits

(Annualized monthly observations, percentages)

\begin{tabular}{lcrrr}
\hline \multirow{2}{*}{ Country } & \multicolumn{2}{c}{ Average rate of interest } & \multicolumn{2}{c}{ Standard deviation } \\
\cline { 2 - 5 } & Before IT & After IT & Before IT & After IT \\
\cline { 2 - 4 } Brazil & 132.47 & 16.80 & 133.56 & 3.54 \\
Chile & 23.02 & 4.57 & 13.87 & 2.06 \\
Colombia & 31.16 & 10.19 & 4.35 & 4.82 \\
Mexico & 36.78 & 4.10 & 24.85 & 1.83 \\
Peru & 17.21 & 2.96 & 26.76 & 0.40 \\
Average & 86.81 & 10.36 & 40.22 & 3.40 \\
\hline
\end{tabular}

Source: Authors' calculations on the basis of International Monetary Fund, International Financial Statistics.

TABLE 6

Latin America (five countries): gdp growth

(Annualized quarterly observations, percentages)

\begin{tabular}{|c|c|c|c|c|}
\hline \multirow{2}{*}{ Country } & \multicolumn{2}{|c|}{ Average rate of GDP growth } & \multicolumn{2}{|c|}{ Standard deviation } \\
\hline & Before IT & After IT & Before IT & After IT \\
\hline Brazil & 2.02 & 3.18 & 2.45 & 1.64 \\
\hline Chile & 6.28 & 4.31 & 3.66 & 1.26 \\
\hline Colombia & 3.09 & 2.93 & 1.34 & 3.35 \\
\hline Mexico & 3.36 & 2.74 & 3.59 & 2.16 \\
\hline Peru & 3.99 & 6.08 & 4.21 & 1.69 \\
\hline Average & 3.75 & 3.85 & 3.05 & 2.02 \\
\hline
\end{tabular}

Source: Authors' calculations on the basis of statistical data from the website of the Economic Commission for Latin America and the Caribbean (ECLAC).

Note: Numbers are annual rates of GDP growth on the basis of quarterly observations. Sample: first quarter of 1992 to fourth quarter of 2007. 
FIGURE 1

Average and variability of inflation, economic growth and interest rates in it and non-it countries

(Jan. 2000 - Dec. 2007)

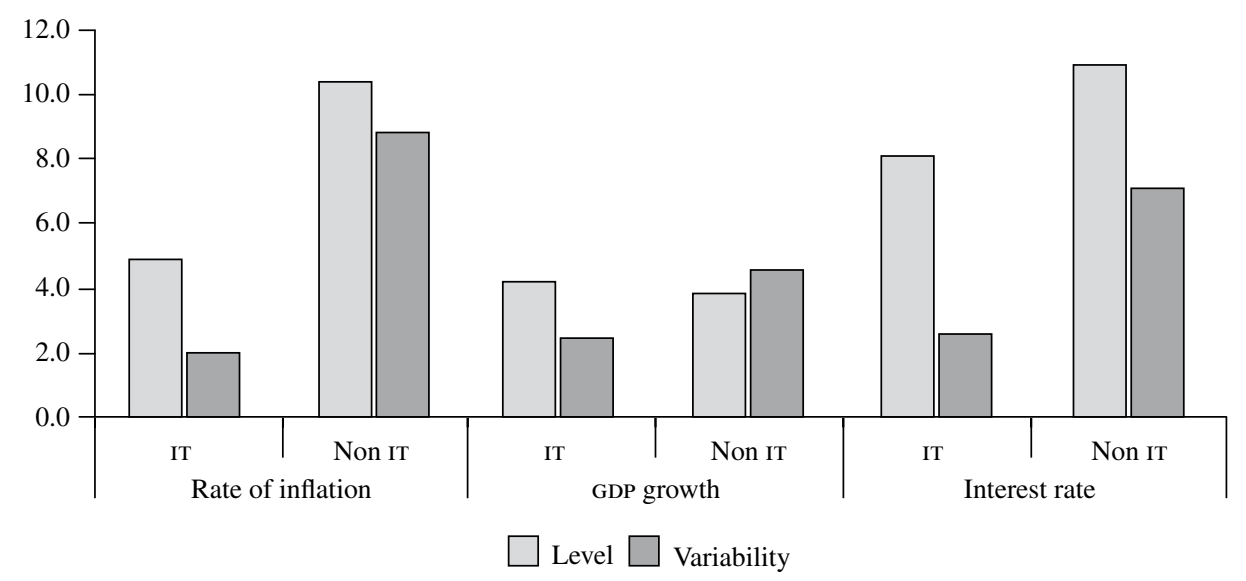

Source: Authors' calculations based on statistical data from the website of the Economic Commission for Latin America and the Caribbean (ECLAC) and International Monetary Fund, International Financial Statistics.

\section{III}

\section{Time Series and Panel Analysis}

\section{Time series regressions}

In this section we perform regressions with dummy variables, following the Ball and Sheridan (2005) methodology, to assess whether the levels and variability of three variables (the rate of inflation, the short-run interest rate, and GDP growth) have significantly changed between the pre-IT and post-IT periods of the ITers.

For this purpose, we estimate the following equation:

$$
x_{i, t}=\alpha_{i}+\delta_{i} F_{i, t}+\gamma_{i} x_{L A T, t}+\theta_{i} G B_{i, t}+\varepsilon_{i, t}
$$

Where $x_{i, t}$ is the variable under analysis of country $i$ corresponding to period $t$, and $F_{i, t}$ is a dummy that takes value 1 during the periods where country $i$ applies IT and value 0 during the rest of the sample. Parameter $\delta_{i}$ measures the effect of IT on the variable $x_{i, t}$.

Equation (1) includes two control variables in order to isolate the pure effect of IT. The first one, $x_{L A T, t}$, stands for the average of $x_{i, t}$ of a large group of Latin American countries. It is included to avoid the biased estimations of parameter $\delta_{i}$ that arise when the variable $x_{i, t}$ converges towards a common mean in the sample of countries. For instance, if $x_{i, t}$ is the inflation rate in Chile, the observed reduction in the value of this variable between the pre- and post-IT periods could, in fact, be created by a general trend in the entire group of countries and not by the implementation of IT. The second control variable, $G B_{i, t}$, captures the strength of the public budget and is measured by the ratio of proceeds over expenditures of the central government.

Ball and Sheridan (2005) used a similar methodology to analyse the effects of IT in a group of industrialized countries, but without conducting separate estimations for each country.

We first estimate equation (1) for the level and standard deviation of the rate of inflation. Inflation is measured by the annual rate of variation in the consumer price index, and its variability is approximated by its standard deviation. In order to more accurately determine the incidence of IT on these variables, we perform regressions for three period samples that differ in the starting date of the pre-IT period. The first one starts in January 1981, the second begins in January 1992, and the third starts in January 1996. If the implementation of IT significantly changes the evolution of the variables (in a 
TABLE 7

Latin America (five countries): inflation rate for three periods

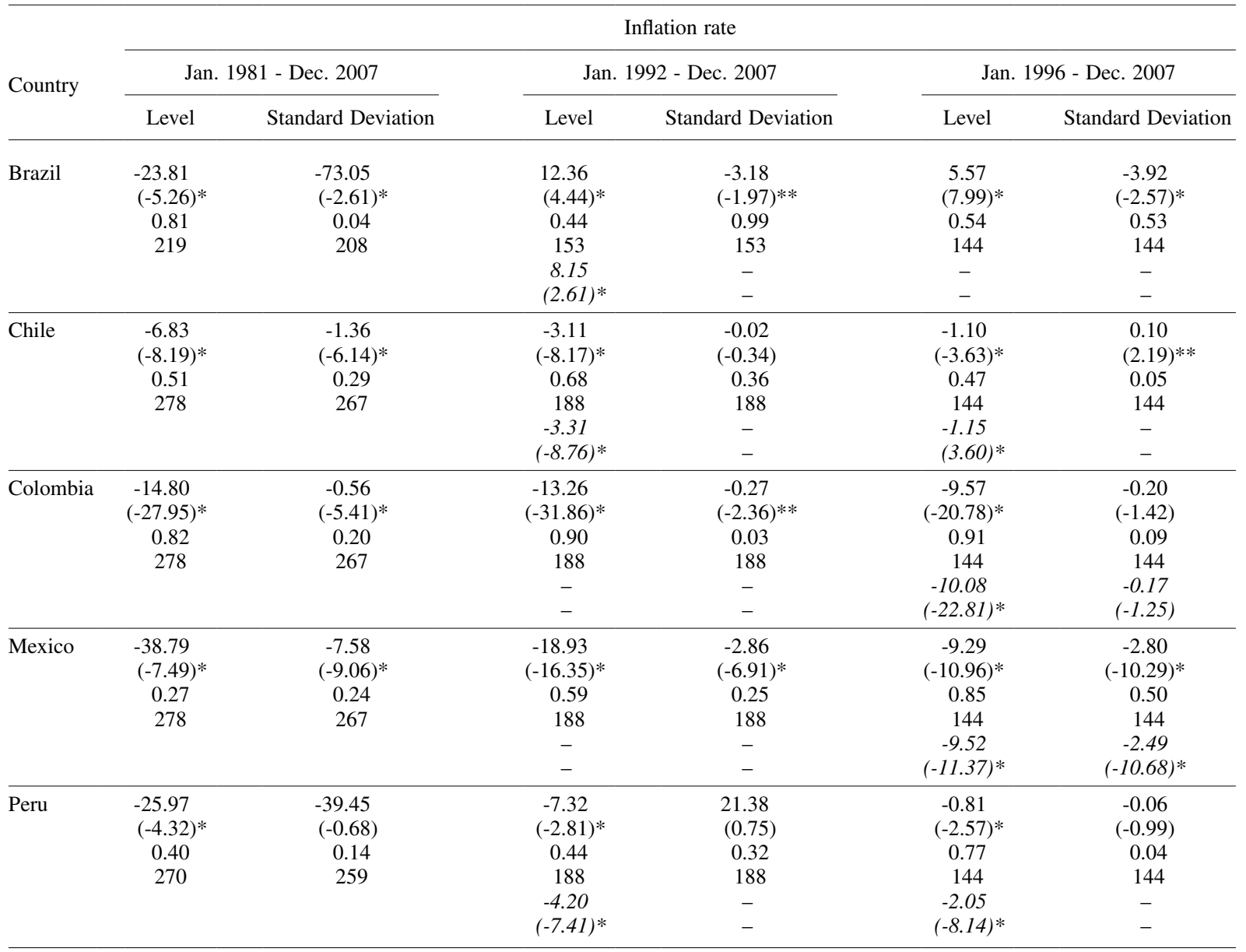

Source: International Monetary Fund, International Financial Statistics.

Note: Monthly data. For each country:

- The first row shows the estimated value of $\delta_{i}$.

- The second row shows the $t$-statistics under the null hypothesis $H_{0}: \delta_{i}=0$. The significance levels are $1 \%(*)$ and $5 \%(* *)$, respectively.

- The third and fourth rows show the $\bar{R}^{2}$ statistics and the number of observations, respectively.

- Cells in rows five and six containing numbers in italics correspond to the cases where the government budget is statistically significant. Row five shows the estimated value of $\delta_{i}$ and row six shows its $t$-statistics. Where no results are given for this estimation the government budget is not statistically significant.

similar way as a structural change), we would expect that the effects of IT will be stronger and more statistically significant for longer pre-IT subperiods.

Table 7 shows the regression results for the inflation rate of each IT country. The first two columns offer the estimation of $\delta_{i}$ for the level and the standard deviation of inflation, corresponding to the longest period sample, January 1981 to December 2007. The control variable $G B_{i, t}$ is not included due to the lack of monthly data for many observations prior to 1992. According to the estimated values of these parameters and of their $t$ statistics, IT has been very effective in reducing both inflation and its variability in each country. For instance, in the case of Chile, the values $\delta_{\text {Chile }}=-6.83$ and $\delta_{\text {Chile }}$ $=-1.36$ mean that the inflation rate and its variability declined by 6.83 percentage points and 1.36 percentage points on average, respectively, in the post-IT period compared with the pre-IT period. The $t$ statistics (-8.19 and -6.14) allow us to clearly reject the null hypothesis of non-significance in each of these estimations.

Columns three to six of table 7 report the results for two shorter periods including the variable $G B_{i, t}$ in 
the regressions. When $G B_{i, t}$ is statistically significant, the estimated value of $\delta_{i}$ and its $t$-statistics are reported in italic numbers in rows five and six, respectively, for the corresponding countries. For comparison purposes, in those cases we also performed the same regressions excluding $G B_{i, t}$, with the results that appear in the first and second rows for each country. As can be seen, except for the two shorter periods in Brazil, $\delta_{i}$ is always negative and statistically significant in regressions with the level of inflation and also in most regressions with inflation variability. Moreover, the inclusion of $G B_{i, t}$ generally improves the statistical significance of parameter $\delta_{i}$.
To sum up, the regression results indicate that both the level and variability of inflation have been negatively affected by the adoption of the IT regime.

Table 8 shows the results of the regressions for the annualized rate of interest of bank deposits calculated with monthly observations. For reasons of data availability, the estimations are restricted to the shorter periods, from January 1992 to December 2007 and from January 1996 to December 2007.

We observe that the adoption of IT led to a significant reduction in both the level and variability of the nominal interest rate, except for interest rate variability in Brazil

TABLE 8

Latin America (five countries): interest rate

\begin{tabular}{|c|c|c|c|c|}
\hline \multirow{3}{*}{ Country } & \multicolumn{4}{|c|}{ Interest rate } \\
\hline & \multicolumn{2}{|c|}{ Jan. 1992 - Dec. 2007} & \multicolumn{2}{|c|}{ Jan. 1996 - Dec. 2007} \\
\hline & Level & Standard Deviation & Level & Standard Deviation \\
\hline Brazil & $\begin{array}{c}-3.00 \\
(-1.86)^{* * *} \\
0.64 \\
153 \\
-6.90 \\
(-4.69) *\end{array}$ & $\begin{array}{l}4.06 \\
(1.93)^{* * *} \\
0.99 \\
153 \\
- \\
-\end{array}$ & $\begin{array}{c}-4.81 \\
(-4.33)^{*} \\
0.60 \\
144 \\
-6.19 \\
(-5.46)^{*}\end{array}$ & $\begin{array}{c}-4.10 \\
(-9.61)^{*} \\
0.47 \\
144 \\
- \\
-\end{array}$ \\
\hline Chile & $\begin{array}{c}-8.50 \\
(-13.44)^{*} \\
0.59 \\
188 \\
- \\
-\end{array}$ & $\begin{array}{c}-3.52 \\
(-13.85)^{*} \\
0.56 \\
188 \\
-3.35 \\
(-13.24)^{*}\end{array}$ & $\begin{array}{c}-5.88 \\
(-8.62)^{*} \\
0.65 \\
144 \\
-5.15 \\
(-7.85)^{*}\end{array}$ & $\begin{array}{c}-2.37 \\
(-15.37)^{*} \\
0.66 \\
144 \\
-2.39 \\
(-17.85)\end{array}$ \\
\hline Colombia & $\begin{array}{c}-19.62 \\
(-26.75)^{*} \\
0.81 \\
188 \\
- \\
-\end{array}$ & $\begin{array}{c}-1.29 \\
(-4.76)^{*} \\
0.13 \\
188 \\
- \\
-\end{array}$ & $\begin{array}{c}-12.38 \\
(-12.01)^{*} \\
0.84 \\
144 \\
- \\
-\end{array}$ & $\begin{array}{c}-0.94 \\
(-3.06)^{*} \\
0.23 \\
144 \\
-0.92 \\
(-3.06)^{*}\end{array}$ \\
\hline Mexico & $\begin{array}{c}-16.52 \\
(-15.34)^{*} \\
0.56 \\
188 \\
- \\
-\end{array}$ & $\begin{array}{c}-3.22 \\
(-8.31)^{*} \\
0.32 \\
188 \\
- \\
-\end{array}$ & $\begin{array}{c}-8.11 \\
(-9.30)^{*} \\
0.78 \\
144 \\
-7.16 \\
(-9.62)\end{array}$ & $\begin{array}{c}-2.67 \\
(-10.90)^{*} \\
0.51 \\
144 \\
-2.36 \\
(-10.33)\end{array}$ \\
\hline Peru & $\begin{array}{c}-7.94 \\
(-7.96)^{*} \\
0.36 \\
188 \\
-7.21 \\
(-24.26) *\end{array}$ & $\begin{array}{l}-5.54 \\
(-2.53)^{* *} \\
0.05 \\
188 \\
-0.13 \\
(-1.88) * * *\end{array}$ & $\begin{array}{c}-5.78 \\
(-15.76)^{*} \\
0.83 \\
144 \\
-6.24 \\
(-17.60) *\end{array}$ & $\begin{array}{c}-0.33 \\
(-5.19) * \\
0.27 \\
144 \\
-0.12 \\
(-1.88) * * *\end{array}$ \\
\hline
\end{tabular}

Source: International Monetary Fund, International Financial Statistics.

Note: Monthly data. For each country:

- The first row shows the estimated value of $\delta_{i}$.

- The second row shows the t-statistics under the null hypothesis $H_{0}: \delta_{i}=0$.

- The significance levels are $1 \%(*), 5 \%(* *)$ and $10 \%(* * *)$, respectively.

- The third and fourth rows show the $\bar{R}^{2}$ statistics and the number of observations, respectively.

- Cells in rows five and six containing numbers in italics correspond to the cases where the government budget is statistically significant.

- Row five shows the estimated value of $\delta_{i}$ and row six shows its $t$-statistics. Where no results are given for this estimation the government budget is not statistically significant. 
during the first period. As in the preceding table, the results with the inclusion of $G B_{i, t}$ (with numbers in italics) are reported only when the government budget is statistically significant. In those cases, $G B_{i, t}$ clearly improves the statistical quality of the results.

Table 9 reports the results of the regression for GDP growth on a quarterly basis. Estimations are limited to the two shorter samples for reasons of data availability. Since the inclusion of $G B_{i, t}$ delivered non-statistically significant estimations, the corresponding results are not reported in the table. As can be seen, in the majority of cases IT significantly reduces the variability of GDP growth. However, results concerning average growth are less conclusive. In some cases, the impact is positive (Brazil and Peru during the period 1996-2007), but in most cases it is non-significant or even negative (Chile, 1992-2007, and Mexico, 1996-2007).

\section{Panel regressions}

In this section we perform panel regressions that include one dummy deemed to capture the differences in the macroeconomic results between ITers and NITers.
Consider the following equation:

$$
x_{i, t}=\alpha+\delta F_{i, t}+\varepsilon_{i, t}
$$

Where $x_{i, t}$ stands for the interest variable, and $F_{i, t}$ is a dummy variable that takes the value 1 for the observed data from IT countries and the value 0 for data from NIT economies. The parameter $\delta$ measures the difference (on average) between the $x_{i, t}$ values of the two groups of countries.

We run regressions for the three variables of interest - the rate of inflation, the bank deposit interest rate and GDP growth - using monthly and quarterly data over the period from January 2000 to December 2007. The variables are defined and measured in the same way as in section II.2(a).

Table 10 shows the results for all the regressions. As can be seen, the estimated values of $\delta$ always have the appropriate sign and are statistically significant (at the $1 \%$ level) except for the level of GDP growth. The results referring to the rate of inflation (presented in the first two columns) indicate that the IT group obtained an average rate of inflation 4.95 percentage points lower

TABLE 9

Latin America (five countries): gdp growth

\begin{tabular}{|c|c|c|c|c|}
\hline \multirow{3}{*}{ Country } & \multicolumn{4}{|c|}{ GDP growth } \\
\hline & \multicolumn{2}{|c|}{ 1992:QI - 2007:QIV } & \multicolumn{2}{|c|}{ 1996:QI - 2007:QIV } \\
\hline & Level & Standard Deviation & Level & Standard Deviation \\
\hline Brazil & $\begin{array}{c}0.59 \\
(1.37) \\
0.34 \\
61\end{array}$ & $\begin{array}{c}-0.27 * * \\
(-2.02) \\
0.05 \\
58\end{array}$ & $\begin{array}{c}1.51^{*} \\
(4.26) \\
0.59 \\
48\end{array}$ & $\begin{array}{c}-0.25 \\
(-1.57) \\
0.04 \\
48\end{array}$ \\
\hline Chile & $\begin{array}{c}-1.86^{*} \\
(-3.23) \\
0.39 \\
61\end{array}$ & $\begin{array}{c}-0.46^{*} \\
(-3.10) \\
0.25 \\
58\end{array}$ & $\begin{array}{c}-0.98 \\
(-1.55) \\
0.33 \\
48\end{array}$ & $\begin{array}{c}-0.39 * * \\
(-2.14) \\
0.25 \\
48\end{array}$ \\
\hline Colombia & $\begin{array}{c}0.45 \\
(0.73) \\
0.58 \\
52\end{array}$ & $\begin{array}{c}0.04 \\
(0.18) \\
0.22 \\
49\end{array}$ & $\begin{array}{c}0.67 \\
(1.05) \\
0.59 \\
48\end{array}$ & $\begin{array}{c}0.04 \\
(0.18) \\
0.22 \\
46\end{array}$ \\
\hline Mexico & $\begin{array}{c}-0.55 \\
(-0.78) \\
0.14 \\
61 \\
\end{array}$ & $\begin{array}{c}-0.62 * * \\
(-2.59) \\
0.08 \\
58 \\
\end{array}$ & $\begin{array}{c}-1.93 * * \\
(-2.67) \\
0.30 \\
48 \\
\end{array}$ & $\begin{array}{c}-0.81 * \\
(-3.17) \\
0.15 \\
48 \\
\end{array}$ \\
\hline Peru & $\begin{array}{c}1.01 \\
(1.17) \\
0.27 \\
61\end{array}$ & $\begin{array}{c}-1.09^{*} \\
(-7.12) \\
0.46 \\
58\end{array}$ & $\begin{array}{c}2.45^{*} \\
(3.88) \\
0.55 \\
48\end{array}$ & $\begin{array}{c}-1.03 * \\
(-6.15) \\
0.44 \\
48\end{array}$ \\
\hline
\end{tabular}

Source: Statistical data from the website of the Economic Commission for Latin America and the Caribbean (ECLAC).

Note: Quarterly data. The first row shows the estimated value of $\delta_{i}$.

The second row presents the $t$-statistics under the null hypothesis $H_{0}: \delta_{i}=0$. The significance levels are: $1 \%(*)$ and $5 \%(* *)$, respectively.

The third and fourth rows show the $\bar{R}^{2}$ statistics and the number of observations, respectively. 
Cross-section regressions

\begin{tabular}{|c|c|c|c|c|c|c|}
\hline & \multicolumn{2}{|c|}{ Jan. 2000 - Dec. 2007} & \multicolumn{2}{|c|}{ Jan. 2000 - Dec. 2007} & \multicolumn{2}{|c|}{ 2000:QI - 2007:QIV } \\
\hline & \multicolumn{2}{|c|}{$\begin{array}{l}\text { Inflation rate } \\
\text { (Monthly data) }\end{array}$} & \multicolumn{2}{|c|}{$\begin{array}{c}\text { Interest rate } \\
\text { (Monthly data) }\end{array}$} & \multicolumn{2}{|c|}{$\begin{array}{c}\text { GDP growth } \\
\text { (Quarterly data) }\end{array}$} \\
\hline & Level & Standard Deviation & Level & Standard Deviation & Level & Standard Deviation \\
\hline IT & $\begin{array}{c}-4.95 \\
(-7.63)^{*} \\
1440 \\
0.04\end{array}$ & $\begin{array}{c}-1.71 \\
(-8.93)^{*} \\
1440 \\
0.05\end{array}$ & $\begin{array}{c}-2.60 \\
(-5.14)^{*} \\
1440 \\
0.02\end{array}$ & $\begin{array}{c}-1.20 \\
(-6.39)^{*} \\
1440 \\
0.03\end{array}$ & $\begin{array}{c}0.12 \\
(0.30) \\
480 \\
-0.02\end{array}$ & $\begin{array}{c}-0.37 \\
(-3.19) * \\
480 \\
0.02\end{array}$ \\
\hline
\end{tabular}

Source: Statistical data from the website of the Economic Commission for Latin America and the Caribbean (ECLAC) and International Monetary Fund, International Financial Statistics.

Note: The first row shows the estimated value of $\delta$.The numbers in parentheses show the $t$-statistics under the null hypothesis $H_{0}$ : $\delta=0$. The significance level is $1 \%(*)$. Rows three and four show the number of panel observations and the $\bar{R}^{2}$ statistics, respectively. The IT countries include Brazil, Chile, Colombia, Mexico and Peru. The group of NIT countries is made up of Argentina, Bolivarian Republic of Venezuela, Costa Rica, Dominican Republic, Ecuador, El Salvador, Panama, Paraguay, Plurinational State of Bolivia and Uruguay.

than that of the NIT group. The IT group also improved the results concerning the variability of the inflation rate: the standard deviation decreased by 1.71 percentage points with respect to the NITers. As regards the nominal interest rate (third and fourth columns), the improvements afforded by the IT regime are also evident in terms of both lower levels and decreased variability.

The results referring to GDP growth deserve additional comments. First, they are obtained using quarterly data (480 observations). Second, although the impact parameter has the correct sign, the estimated value is very small and not statistically significant: t-statistics equal to 0.30 . Third, IT clearly decreases GDP growth variability, since the impact variable has a negative sign and is statistically significant at the $1 \%$ level. IT contributed to reducing growth rate variability by an average of 0.37 percentage points in ITers compared with NITers. These results fully confirm our findings in the time regression analysis of GDP growth effects, where the advantage of ITers compared with NITers was detected in variability but not in levels.

\section{Treatment effects}

The way that the econometric tests applied so far assess the influence of qualitative variables, such as the adoption of IT, may suffer from endogeneity problems. To overcome this difficulty, in this section we estimate a model of treatment effects that is especially designed to investigate the impact of non-observable variables on quantitative ones and to solve the self-selection bias. We apply the model suggested by Heckman (1979), Maddala (1983) and Greene (2003) to estimate the effects of IT on the mean and variability of the three interest variables. The method consists of two sequential estimations. We first estimate a probit equation, which aims at assessing the extent to which some variables proposed in the empirical literature affect the probability of adopting an IT regime, and then three outcome equations that relate each interest variable with its main determinants, including the adoption of IT. The model is as follows:

$$
\begin{gathered}
y_{i t}=\beta^{\prime} x_{i t}+\delta I T_{i t}+u_{i t} \\
I T_{i t}= \begin{cases}1 & \text { if } I T_{i t}^{*}>0 \\
0 & \text { otherwise }\end{cases} \\
I T_{i t}^{*}=\gamma^{\prime} w_{i t}+\zeta_{i t}
\end{gathered}
$$

Equation (3) is the outcome equation valid for each interest variable $y_{i t}$. It shows that $y_{i t}$ (the value of $y$ in country $i$ during quarter $t$ ) has two main determinants: vector $x_{i t}$, which includes a set of observable variables liable to affect $y_{i t}$, and a dichotomy variable, $I T_{i t}$, which takes the value $l$ if country $i$ in period $t$ is an ITer, and the value 0 otherwise, as indicated by the expression (4). Regarding the components of vector $x_{i t}$, we have selected four variables included in standard macroeconomic models, i.e. gross formation of fixed capital $\left(g f f k_{i t}\right)$, international openness $\left(\right.$ open $\left._{i t}\right)$, the growth rate of the money supply $\left(m_{1}\right)$ and the public deficit as a percentage of GDP $\left(d e f_{i t}\right)$. The parameter $\delta$ measures the effect of adopting IT on variable $y_{i t}$.

Columns two to four of table 11 describe the hypothesized signs of the effects of the exogenous 
Hypothesized signs in the treatment effects equations

\begin{tabular}{|c|c|c|c|c|}
\hline \multirow[b]{2}{*}{ Control variable } & \multicolumn{3}{|c|}{ Output equation } & \multirow[t]{2}{*}{ Probit equation } \\
\hline & Inflation rate & Short-run interest rate & GDP growth & \\
\hline gffk $k_{i t}$ & & & + & \\
\hline open $_{i t}$ & - & - & + & - \\
\hline$I T_{i t}$ & - & - & $+/-$ & \\
\hline$m_{1}$ & + & - & & \\
\hline$d e f_{i t}$ & $+/-$ & $+/-$ & & $+/-$ \\
\hline$d e p_{i t}$ & & & & + \\
\hline$c a_{i t}$ & & & & - \\
\hline extdebt $t_{i t}$ & & & & - \\
\hline
\end{tabular}

Source: The authors, on the basis of conventional macroeconomic models.

variables on the levels of the three endogenous ones in the outcome equations. As far as the nominal variables (inflation and interest rates) are concerned, it seems clear that openness should result in a drop in both nominal levels. Moreover, the rate of money growth is deemed to increase inflation and reduce short-run interest rates. However, there are no conclusive reasons for the sign of the fiscal deficit. If fiscal deficits are predominantly debt-financed, they should push up interest rates and lower inflation. But if they cause money expansions, effects in the opposite direction must be expected. As regards the effects on economic growth, the first two variables of vector $x_{i t}$ are expected to impact positively. The favourable impact of $g f f k_{i t}$ on growth is extensively documented in the traditional models of economic growth, and the positive contribution of international openness to economic growth is empirically demonstrated by proponents of the export-led growth hypothesis (see, for instance, Feder, 1983; Helpman and Krugman, 1985; and Krugman 1987) and by the endogenous growth theory (Romer, 1986; Grossmann and Helpmann, 1995; and Alesina and Rodrick, 1999). Empirical evidence of the positive effects of international trade on economic growth for some groups of EMEs is provided by Hassan (2005) and Ekanayake, Vogel and Veeramachenemi (2003).

Equation (5) is the probit equation, establishing that the probability of adopting IT is represented by a non-observed variable $I T_{i t}^{*}$, which in turn depends on a set of factors included in vector $w_{i t}$. After looking at the potential determinants of IT that have been most frequently suggested in the literature - see, for instance, Gerlach (1999), Hu (2006), Batini and Laxton (2007) and Leyva (2008) — we have selected the following variables: (i) fiscal deficit, (ii) economic openness, (iii) the strength of financial development, (iv) vulnerability to external shocks, and (v) the amount of external liabilities denoted in foreign currency.

Let us now explain how the variables included in the probit equation are measured, and the sign of their expected influence on the probability of adopting an IT regime (see column four of table 12). The fiscal deficit is measured as a percentage of GDP and, as in the case of the outcome equation, there are no definitive arguments to clearly hypothesize the sign of this variable. On the one hand, central bank independence (an important ingredient of IT regimes) forces governments to adopt more austere fiscal policies but, on the other hand, the adoption of IT might be endogenously decided as a remedy for weak public budgetary practices. Consequently, either of the two signs may be expected. Economic openness is measured with the amount of imports plus exports as a share of GDP. Since openness increases the rate of pass-through from exchange-rate variations to domestic prices, it interferes with the control of inflation and discourages the central bank from adopting IT. This is especially true in emerging market economies because their pass-through coefficients are higher than those of the industrialized countries (García-Solanes and Torrejón-Flores, 2010). Moreover, as emphasized by Mishkin (2001), Eichengreen (2002) and Willet (2002), increasing trade and financial openness under exchange-rate flexibility may cause financial instability in EMEs with IT. Thus, it is reasonable to expect a negative relationship between openness and the probability of adopting IT.

The soundness, health and development of a financial system may be proxied by the total amount of bank deposits as a share of GDP. Given that this variable 
is a key element - if not a prerequisite — of IT strategy, we may assume that it contributes to the adoption of IT. Then, the sign of its effects on the adoption of IT must be positive. We measure vulnerability to external shocks with the current account deficit. High external imbalances make the central bank less inclined to adopt IT, which indicates that the sign of this variable should be negative. Finally, the amount of external liabilities in foreign currencies is measured with the stock of external debt denoted in foreign currency. It is easy to understand that, since high levels of this variable hinder the operation of flexible exchange rates, external liabilities reduce the probability of adopting IT. ${ }^{3}$ Consequently, the minus sign is our guess.

To estimate the system (3) to (5), we may apply either the maximum likelihood method, or the two-step procedure suggested by Heckman (1979), which has been well explained by Maddala (1983) and Greene (2003) and used by Edwards (2004). Given that we have chosen the two-step methodology, a brief explanation of it is in order. In the first step, we apply the probit method to estimate the parameter $\gamma$, which is then used in equation (5) to estimate the variable $I T_{i t}^{*}$. The result is applied in equation (4) to derive the dichotomy variable $I T_{i t}$. In the second step, we estimate the output equations. However, in order to obtain a consistent and non-overestimated value of the parameter $\delta$ in equation (3) we must incorporate in that equation the variable $\hat{\lambda}_{i t}$, which is defined as the ratio between the density function and the accumulated distribution of $I T_{i t}^{*}: \hat{\lambda}_{i t}=f\left(I \hat{T}_{i t}^{*}\right) / F\left(I \hat{T}_{i t}^{*}\right)$ (see Greene,

\footnotetext{
${ }^{3}$ Although debt dollarization is a clear obstacle to IT implementation, it does not per se preclude the use of IT as an effective policy regime. The case of the shighly dollarized Peru is a good example, as shown by Leiderman, Maino and Parrado (2006).
}

2003, chap. 22). Consequently, we estimate the enlarged equation, $y_{i t}=\beta^{\prime} x_{i t}+\delta I T_{i t}+\beta_{\hat{\lambda}} \hat{\lambda}_{i t}+\xi_{i t}$, to obtain the values of the parameters $\beta, \beta_{\hat{\lambda}}$ and $\delta$.

Table 12 reports the estimation results of the system (3)-(5) for the three interest variables. As far as the probit equation is concerned, all the variables selected as determinants of the probability of adopting IT have the hypothesized sign and are statistically significant at the $1 \%$ level, which means that the probability of adopting the IT regime is very well captured by the selected variables and is favoured by the occurrence of the following factors: (i) fiscal imbalances, (ii) limited economic openness, (iii) strength of the domestic financial system, (iv) low current account deficits, and (v) low levels of external debt.

As regards the outcome equations, all estimations exhibit very good statistical quality. However, there are important differences between them. Thus, the level and variability of both inflation and short interest rates are very well explained by openness, money supply growth, public deficit and IT. All these determinants exhibit the hypothesized signs presented in table 11. Interestingly, money supply growth significantly affects the interest rate level but not its volatility. The most relevant finding is that IT has a clear negative and significant incidence in both the level and volatility of inflation and interest rates, confirming the results of the former sections. Turning now to the growth equation, the results presented in columns 5 and 6 of table 12 indicate that economic growth is favoured by gross formation of fixed capital and by international openness. Adoption of the IT regime contributes significantly to lowering variability growth, but it does not significantly impact the level of GDP growth, confirming, once again, our previous findings in this paper. This result is unsurprising since the effects of IT on growth should appear over time horizons longer that those of our samples. 
TABLE 12

Treatment effects: the impact of inflation targeting (2000:QI - 2007:QIV)

Treatment variable: application of the inflation-target strategy $\left(I T_{i t}^{*}\right)$. Probit equation.

\begin{tabular}{|c|c|c|c|c|c|c|}
\hline Variable & IT & & & & & \\
\hline$c$ & $\begin{array}{c}5.468^{*} \\
(8.769)\end{array}$ & & & & & \\
\hline$d e f_{i t}$ & $\begin{array}{c}0.142 * \\
(4.305)\end{array}$ & & & & & \\
\hline open $_{i t}$ & $\begin{array}{c}-0.064^{*} \\
(-9.631)\end{array}$ & & & & & \\
\hline$d e p_{i t}$ & $\begin{array}{c}0.089^{*} \\
(8.070)\end{array}$ & & & & & \\
\hline$c a_{i t}$ & $\begin{array}{c}-0.214^{*} \\
(-7.051)\end{array}$ & & & & & \\
\hline extdebt $_{i t}$ & $\begin{array}{c}-0.100^{*} \\
(-8.810)\end{array}$ & & & & & \\
\hline \multicolumn{7}{|c|}{ Outcome variable } \\
\hline Variable & Inflation & $\begin{array}{l}\text { Inflation } \\
\text { standard } \\
\text { deviation }\end{array}$ & Interest rate & $\begin{array}{l}\text { Interest rate } \\
\text { standard } \\
\text { deviation }\end{array}$ & GDP growth & $\begin{array}{l}\text { GDP growth } \\
\text { standard } \\
\text { deviation }\end{array}$ \\
\hline$c$ & $\begin{array}{l}5.045^{* * * *} \\
(1.656)\end{array}$ & $\begin{array}{c}0.570 \\
(0.655)\end{array}$ & $\begin{array}{c}22.869^{*} \\
(9.916)\end{array}$ & $\begin{array}{l}2.100 * * \\
(2.517)\end{array}$ & $\begin{array}{c}0.149 \\
(0.148)\end{array}$ & $\begin{array}{c}1.178^{*} \\
(4.117)\end{array}$ \\
\hline$g f f k_{i t}$ & & & & & $\begin{array}{c}0.159^{*} \\
(3.681)\end{array}$ & $\begin{array}{c}-0.014 \\
(-1.012)\end{array}$ \\
\hline open $_{i t}$ & $\begin{array}{c}-0.102 * \\
(-6.285)\end{array}$ & $\begin{array}{c}-0.022 * \\
(-4.840)\end{array}$ & $\begin{array}{c}-0.078^{*} \\
(-6.306)\end{array}$ & $\begin{array}{c}-0.027 * \\
(-5.970)\end{array}$ & $\begin{array}{l}0.010^{* * * *} \\
(1.681)\end{array}$ & $\begin{array}{c}-0.013 * \\
(-5.641)\end{array}$ \\
\hline$I T_{i t}$ & $\begin{array}{l}-3.362^{* *} \\
(-1.966)\end{array}$ & $\begin{array}{l}-1.118^{* *} \\
(-2.289)\end{array}$ & $\begin{array}{c}-7.290^{*} \\
(-5.633)\end{array}$ & $\begin{array}{l}-1.177^{* *} \\
(-2.514)\end{array}$ & $\begin{array}{c}0.062 \\
(0.329)\end{array}$ & $\begin{array}{l}-0.236^{* *} \\
(-1.923)\end{array}$ \\
\hline$\hat{\lambda}_{i t}$ & $\begin{array}{c}17.188^{*} \\
(3.527)\end{array}$ & $\begin{array}{c}4.110^{*} \\
(2.951)\end{array}$ & $\begin{array}{l}-6.964 * * * \\
(-1.888)\end{array}$ & $\begin{array}{l}1.918 \\
(1.437)\end{array}$ & $\begin{array}{c}-0.037 \\
(-0.139)\end{array}$ & $\begin{array}{c}1.709^{*} \\
(3.635)\end{array}$ \\
\hline$m_{1}$ & $\begin{array}{l}0.088^{* *} \\
(2.257)\end{array}$ & $\begin{array}{c}0.049 * \\
(4.383)\end{array}$ & $\begin{array}{c}-0.083^{*} \\
(-2.821)\end{array}$ & $\begin{array}{c}0.017 \\
(1.570)\end{array}$ & & \\
\hline$d e f_{i t}$ & $\begin{array}{l}0.297 * * * \\
(1.613)\end{array}$ & $\begin{array}{c}0.152 * \\
(2.882)\end{array}$ & $\begin{array}{l}-0.325 * * \\
(-2.330)\end{array}$ & $\begin{array}{l}-0.102 * * \\
(-2.023)\end{array}$ & & \\
\hline Observations & 480 & 480 & 480 & 480 & 480 & 480 \\
\hline$\sigma$ & & & & & 0.291 & \\
\hline$\rho$ & & & & & 0.126 & \\
\hline
\end{tabular}

Source: Statistical data from the website of the Economic Commission for Latin America and the Caribbean (ECLAC) and International Monetary Fund, International Financial Statistics.

Note: Level of significance: $1 \%(*) ; 5 \%(* *)$ and $10 \%(* * *)$. Values within parentheses are the quartiles of the typical normal distribution (in the probit estimation) and the values of the $t$-statistics (in outcome estimations). 


\section{IV}

\section{Concluding Remarks}

In this paper we have analysed the extent to which inflation targeting has improved macroeconomic performance in a group of five Latin American countries during their post-IT period. To evaluate the results in relative terms, we have taken as a benchmark 10 Latin American countries that share many institutional features with the five ITers, except for the adoption of an IT regime. We expect that geographical and institutional homogeneity serves to extract more clearly the specific effects of IT.

In order to get a first impression of the likely results of IT on both the average levels and the variability of some domestic variables, in the second section we performed a descriptive analysis and statistical tests with data for the fifteen Latin American countries. In the third section, we applied three different econometric tests to more accurately assess the impact of IT. In the first two econometric tests, based on time series and panel regressions, we used dummy variables to indirectly evaluate the effects of IT on some macroeconomic variables. Since the results of these conventional tests may be affected by endogeneity and self-selection problems, in order to overcome those shortcomings we estimated a treatment effects model especially suited to evaluating the impact of qualitative variables (such as the adoption of IT) on other variables that are easily quantified (such as inflation, interest rates and GDP growth). This is the main and original technical contribution of this paper, compared with the available literature in this field. The results from the three econometric tests confirm the descriptive impressions, signalling IT as responsible for lower levels and variability of both inflation and shortrun interest rates and decreased growth variability in the countries that adopted this regime. However, none of the three econometric tests was able to clarify the effects of IT on average GDP growth. In sum, we provide evidence that adoption of IT in the five Latin American ITers of our sample improved economic performance during the investigated period, probably by anchoring and lowering inflation expectations in those countries.

(Original: English)

Bibliography

Alesina, A. and D. Rodrik (1999), "Distributive politics and economic growth", Quarterly Journal of Economics, vol. 109, No. 2, Cambridge, Massachusetts, The MIT Press.

Ball, L. and N. Sheridan (2005), "Does inflation targeting matter?", The Inflation Targeting Debate, B.S. Bernanke and M. Woodford (eds.), Chicago, University of Chicago Press.

Batini, N. and D. Laxton (2007), "Under what conditions can inflation targeting be adopted? The experience of emerging markets", Monetary Policy under Inflation Targeting, F. Mishkin and K. Schmidt-Hebbel (eds.), Santiago, Chile, Central Bank of Chile.

Berg, A., E. Borensztein and P. Mauro (2002), "An evaluation of monetary regime options for Latin America", imf Working Paper, No. 02/211, Washington, D.C., International Monetary Fund.

Blanchard, O. (2005), "Fiscal dominance and inflation targeting: lessons from Brazil", Inflation Targeting, Debt, and the Brazilian Experience, 1999 to 2003, F. Giavazzi, I. Goldfajn and S. Herrera (eds.), Cambridge, Massachusetts, The MIT Press.

Blejer, M.I. and others (2001), "Inflation targeting in the context of IMF-supported adjustment programs", imf Working Paper, No. 01/31, Washington, D.C., International Monetary Fund.

Brito, R.D. and B. Bystedt (2010), "Inflation targeting in emerging economies: panel evidence", Journal of Development Economics, vol. 91, No. 2, Amsterdam, Elsevier.

Calderón, C. and K. Schmidt-Hebbel (2003a), "Learning the hard way: ten lessons for Latin America's turmoil", Santiago, Chile, Central Bank of Chile, unpublished.

(2003b), "Macroeconomic policies and performance in Latin America", Working Paper, No. 217, Santiago, Chile, Central Bank of Chile.
Calvo, G.A. and F. Mishkin (2003), "The mirage of exchange rate regimes for emerging market countries", Journal of Economic Perspectives, vol. 17, No. 4, Nashville, Tennessee, American Economic Association.

Calvo, G.A. and C. Reinhart (2002), "Fear of floating", Quarterly Journal of Economics, vol. 117, No. 2, Cambridge, Massachusetts, The MIT Press.

Corbo, V., O. Landerretche and K. Schmidt-Hebbel (2002), "Does inflation targeting make a difference", Inflation Targeting: Design, Performance, Challenges, N. Loayza and R. Soto (eds.), Santiago, Chile, Central Bank of Chile.

Edwards, S. (2004), "Thirty years of current account imbalances, current account reversals and sudden stops", imf Staff Papers, vol. 51, special issue, Washington, D.C., International Monetary Fund.

Edwards, S. and E. Levy-Yeyati (2003), "Flexible exchange rates as shock absorbers", European Economic Review, vol. 49, No. 8, Amsterdam, Elsevier, November.

Eichengreen, B. (2002), "Can emerging markets float? Should they inflation target?", Working Paper Series, No. 36, Brasilia, Central Bank of Brazil, February.

Ekanayake, E.M., R. Vogel and B. Veeramacheneni (2003), “Openness and economic growth: empirical evidence on the relationship between output, inward FDI, and trade", Journal of Business Strategies.

Feder, G. (1983), "On exports and economic growth", Journal of Development Economics, vol. 12, No. 1-2, Amsterdam, Elsevier.

García-Solanes, J. and F. Torrejón-Flores (2010), "Devaluation and pass-through in indebted and risky economies", International 
Review of Economics and Finance, vol. 19, No. 1, Amsterdam, Elsevier.

Gerlach, S. (1999), "Who targets inflation explicitly?", European Economic Review, vol. 43, No. 7, Amsterdam, Elsevier.

Gonçalves, C.E.S and J.M. Salles (2008), "Inflation targeting in emerging economies: what do the data say?", Journal of Development Economics, vol. 85, No. 1-2, Amsterdam, Elsevier.

Greene, W. (2003), Econometric Analysis, New Jersey, Prentice Hall.

Grosssman, G. and E. Helpman (1985), "Technology and trade", Handbook of International Economics, G. Grossman and K. Rogoff (eds.), vol. 3, Amsterdam, Elsevier.

Hassan, A.F.M.K. (2005), "Trade openness and economic growth: search for a causal relationship", South Asian Journal of Management, vol. 12, No. 4, Hyderabad, AMDISA, October.

Heckman, J. (1979), "Sample selection bias as a specification error", Econometrica, vol. 47, No. 1, New York, Econometric Society, January.

Helpman, E. and P.R. Krugman (1985), Market Structures and Foreign Trade, Cambridge, Massachusetts, The MIT Press.

Hrncir, M. and K. Smidkova (2003), "The Czech approach to inflation targeting", Macroeconomics, No. 0303019, EconWPA.

Hu, Y. (2006), "The choice of inflation targeting - an empirical investigation", International Economics and Economic Policy, vol. 3, No. 1, Springer.

IMF (International Monetary Fund) (2006), Inflation Targeting and the imf, Washington, D.C., March.

(2005), "Does inflation targeting work in emerging markets?", World Economic Outlook, Washington, D.C., September.

Jonas, J. and F. Mishkin (2005), "Inflation targeting in transition economies: some issues and experience", The InflationTargeting Debate, B. Bernanke and M. Woodford (eds.), Chicago, The University of Chicago Press.

King, M. (2005), Monetary Policy: Practice Ahead of Theory. The Mais Lecture 2005: Speech by the Governor, London, Cass Business School, City University, 17 May.

Krugman, P.R. (1987), The Age of Diminished Expectation, Cambridge, Massachusetts, The MIT Press.

Kvasnicka, M. (2000), "Inflation targeting. Is it suitable for transitional economies?", IV International Conference of Doctoral Students, vol. 1, Brno, Brno University of Technology.

Leiderman, L., R. Maino and E. Parrado (2006), "Inflation targeting in dollarized economies", Working Paper, No. 368, Santiago, Chile, Central Bank of Chile.
Leyva, G. (2008), "The choice of inflation targeting", Working Paper, No. 475, Santiago, Chile, Central Bank of Chile.

Lin, S. and H. Ye (2009), "Does inflation targeting make a difference in developing countries?", Journal of Development Economics, vol. 89, No. 1, Amsterdam, Elsevier.

Maddala, G.S. (1983), Limited-Dependent and Qualitative Variables in Econometrics, New York, Cambridge University Press.

Mishkin, F.S. (2001), "Global financial instability: framework, events, issues", Journal of Economic Perspectives, vol. 13, No. 4, Nashville, Tennessee, American Economic Association. (1999), "International experiences with different monetary policy regimes", Journal of Monetary Economics, vol. 43, No. 3, Amsterdam, Elsevier.

Mishkin, F.S. and M. Savastano (2002), "Monetary policy strategies for emerging market countries: lessons from Latin America", Comparative Economics Studies, vol. 44, No. 2-3, Palgrave Macmillan.

Mishkin, F. and K. Schmidt-Hebbel (2007), "Does inflation targeting make a difference?", Monetary Policy Under Inflation Targeting, F. Mishkin and K. Schmidt-Hebbel (eds.), Santiago, Chile, Central Bank of Chile.

Nogueira, R.P. and M.A. León-Ledesma (2009), "Fear of floating in Brazil: did inflation targeting matter?", North American Journal of Economics and Finance, vol. 20, No. 3, Amsterdam, Elsevier.

Romer, P.M. (1986), "Increasing returns and long run growth", Journal of Political Economy, vol. 94, No. 5, Chicago, University of Chicago Press.

Sims, C. (2005), "Limits to inflation targeting", The Inflation Targeting Debate, B. Bernanke and M. Woodford (eds.), Chicago, The University of Chicago Press.

Svensson, L. (1997), "Inflation forecast targeting: implementing and monitoring inflation targets", European Economic Review, vol. 41, No. 6, Amsterdam, Elsevier.

Valdés, R. (2007), "Success of a flexible IT regime in reducing inflation in Chile", Documentos de política económica, No. 22, Santiago, Chile, Central Bank of Chile, November.

Willett, T.D. (2002), "Fear of floating needn't imply fixed rates: feasible options for intermediate exchange rate regimes", May, unpublished.

Yigit, T.M. (2010), "Inflation targeting: an indirect approach to assess the direct impact", Journal of International Money and Finance, vol. 29, No. 7, Amsterdam, Elsevier. 